http://jmscr.igmpublication.org/home/ ISSN (e)-2347-176x ISSN (p) 2455-0450

crossref DOI: https://dx.doi.org/10.18535/jmscr/v7i10.22

\title{
The Evaluation of Hearing Level between Workers of Cement Industry and Non- Industrial Workers
}

Authors

\section{Dr Fatima Sadia ${ }^{1 *}$, Prof. Dr Momtaz Begum², Dr Shahin Akter ${ }^{3}$, Dr Mohammed Salahuddin Shahed Chowdhury ${ }^{4}$ \\ ${ }^{1}$ Lecturer, Dept. of Physiology, Chattagram Medical College, Chattagram}

${ }^{2}$ Professor and Head, Dept. of Physiology, Chattagram Medical College, Chattagram

${ }^{3}$ Assistant Professor, Dept. of Physiology, Chattagram Medical College, Chattagram

${ }^{4}$ Assistant Professor, Dept. of Hepatology, Chattogram Medical College, Chattagram

*Corresponding Author

\section{Dr Fatima Sadia}

\begin{abstract}
Objective: In this study our main goal is to evaluate the hearing level between workers of cement industry and nonindustrial workers.

Methodology: This Cross-sectional observational study was conducted at Department of Physiology, CHITTAGONG MEDICAL COLLEGE, Chittagong and Heidelbargh Cement Bangladesh Ltd. East Halishar, Chittagong, from January 2017 to December 2018. Where total number of 800 (Eight hundred) subjects were included. During the study, All subjects were selected purposively on the basis of noise exposure study procedure. After selection and proper counseling, the aim, objective and procedure of the study was explained in details to all subjects, in the cement industry.

Result: during the study frequency of hearing loss were $304(50.7 \%) \& 8$ (4\%) in study group and control respectively.50.7\% patients in group-A had hearing loss. $4 \%$ in group-B had this problem. mean duration of employment among the cases according to hearing loss in 8.67 and for normal cases 6.30 .

Conclusion: We can conclude that, the hearing loss caused by exposure to occupational noise has multiple consequences at both the individual and the social level. While various factors contribute to the occurrence of occupational noise induced hearing loss (NIHL) like age, sound level and duration of noise exposure, duration of employment and lack of preventive measures. Lack of knowledge about hearing loss and proper use of protective measures influence hearing loss in cement industries. Further study should be conducted to better outcome.

Keywords: Hearing level, Noise induced hearing loss (NIHL).
\end{abstract}

\section{Introduction}

NIHL is an important public health priority due to spreading industrialization. Exposure to continuous and extensive noise at a level higher than $85 \mathrm{~dB}$ may lead to hearing loss' In early stages of hearing loss, due to noise exposure symptoms usually are difficulties in conversation, difficulty in enjoying TV/Radio at low volume and tinnitus.
A great majority of people working in the industry are exposed to noise. Industrial machines and processes produce industrial noise. In cement industry, the cement production machineries emit offensive noise and vibration due to high acoustic power.

The crusher, cement mill and row mill are the major noise eimission sources where noise levels 
are above $85 \mathrm{~dB}$. The sound pressure levels in these units are $102 \mathrm{~dB}$ in crusher, $100 \mathrm{~dB}$ in cement mills and $99 \mathrm{~dB}$ in row mills, respectively Due to high noise exposure $>90 \mathrm{~dB}$, the workers in these units are prone to develop noise induced hearing damage.

In different studies among workers in different industries, it was found that noise affects the hearing status of the workers. In India, workers of power loom industry, showed that $34 \%$ had mild to moderate hearing loss and $8 \%$ had severe sensorineural hearing loss' In textile industry, 54\% workers had sensory loss of hearing at high frequencies comparing to $18 \%$ at low frequencies. In plastic weavers, hearing threshold was found significantly higher at high frequencies in day shift workers \& continuous shift workers than temporary workers.

Cement industry is one of the noisiest industry with maximal noise level above $104 \mathrm{~dB}$ above the upper permissible level of $85 \mathrm{~dB}$. In studies conducted in Tanjania, Nigeria \& Iran it was observed that maximum noise level was $104 \mathrm{~dB}$ and $106 \mathrm{~dB}$ in crusher unit of cement factory. $[1][2][3][4]$

In this study our main goal is to evaluate the hearing level between workers of cement industry and non- industrial workers.

\section{Objective}

\section{General Objective:}

- To assess the hearing level among the workers of cement industry.

\section{Specific Objective}

- To detect frequency distribution of hearing loss

- To identify mean durations of employment among the cases according to diagnoses

\section{Methodology}

Type of Study: This was a Cross sectional observational study

Place and Period of Study: this study was conducted at Department of Physiology, CHITTAGONG MEDICAL COLLEGE,
Chittagong and Heidelbargh Cement Bangladesh Ltd. East Halishar, Chittagong, from One year (January 2011 to December 2011)

Study Population: Workers in cement industry (both gender) age ranged from 18 to 55 year who are working for more than 2 years (two years of work place noise /www.hear-it.org) were selected as case, while the age and sex matched healthy medical staffs were selected as control.

Sampling Technique: Purposive sampling.

\section{Sample Size:}

A total number of 800 (Eight hundred) subjects were included.

In one study the prevalence of NIHL was approximately $33 \%$ (E.Atameca et al) determine the sample size, the following formula has been used:

$$
\mathrm{n}=\mathrm{Z}^{2} \mathrm{pq} / \mathrm{e}^{2}
$$

Where,

$$
n=\text { The desired sample size. }
$$

$\mathrm{z}=$ The standard normal deviate set at 196 which corresponds to the $95 \%$ confidence level.

$\mathrm{p}=$ the proportion of the target population (Anticipated population proportion) estimated to have a particular characteristics, here, $\mathrm{P}=0.33$, ie: $33 \%$

$\mathrm{e}=$ Degree of accuracy desired (absolute precision), set at 0.033 , ie. $3.3 \%$ (10\% of p)

$$
\mathrm{q}=1-\mathrm{p}
$$

So, The desired sample size will be:

$\mathrm{n}=$

$=779$

$=800$ (approximately).

\section{Grouping of subjects:}

Group A (case/ Study group): Consists of 600 workers of cement industry.

Group: B (Control): Consists of 200 subjects, age and sex matched medical staffs.

\section{Selection Criteria:}

Inclusion Criteria: For both groups

1) Age: Over 18 years to 55 years

2) Duration: of service: More than two years. 
3) No past history of viral disease, drug therapy or any aural pathology which may cause sensory neural hearing loss.

4) Otoscopy: Apparently normal looking tympanic membrane.

\section{Exclusion Criteria}

1) Age: Above 55 years \& Below 18 years (Salud publica de Mexico).

2) Duration of service: Less Than two years.

3) Subject with pathological lesion in ear: (CSOM, ASOM, perforation of tympanic membrane, impacted wax)

\section{For the Controls}

\section{Inclusion Criteria}

1) Age: Over 18 years to 55 years.

2) No past history of viral disease, drug therapy or may aural pathology which may cause sensory neural hearing loss.

3) Otoscopy: Apparently normal looking tympanic membrane.

\section{Sampling Method}

All subjects were selected purposively on the basis of noise exporsure tudy procedure. After selection and proper counseling, the aim, objective and procedure of the study was explained in details to all subjects, in the cement industry. Age and sex matched, not exposed to noise staffs in Chittagong medical college hospital and clinics in Chittagong city were selected as control. The subjects were allowed to withdraw themselves if they like. A informed written consent was taken from all subjects included in the study and detailed personal information, medical and family history were recorded in a preformed questionnaire (Appendix -1)

Height in $\mathrm{cm}$ and weight in $\mathrm{kg}$ were measured by scale (Biospace BSM370), pulse, blood pressure were recorded by aneroid sphygmomanometer. Anemia, jaundice, oedema, dehydration were observed in all subjects.

\section{Data Analysis}

Data were expressed in number and frequency. For statistical analysis chi-square test was used. $\mathrm{P}<0.05$ was accepted as level of significance.

\section{Results}

In table-1 shows frequency distribution of hearing loss in two groups $(n=800)$ where the frequency of hearing loss were $304(50.7 \%) \& 8(4 \%)$ in study group and control respectively. The following table is given below in detail:

Table-1: Frequency distribution of hearing loss in two groups $(\mathrm{n}=800)$.

\begin{tabular}{|l|c|c|c|c|}
\hline \multirow{2}{*}{$\begin{array}{l}\text { HL } \\
\text { loss })\end{array}$} & \multicolumn{2}{|c|}{$\begin{array}{c}\text { Study Group } \\
(\mathrm{n}=600)\end{array}$} & \multicolumn{2}{c|}{$\begin{array}{c}\text { Control } \\
(\mathrm{n}=200)\end{array}$} \\
\cline { 2 - 5 } & $\mathrm{N}$ & $\%$ & $\mathrm{~N}$ & $\%$ \\
\hline Total HL & 304 & 100.0 & 08 & 4 \\
\hline Mild HL & 128 & 42.1 & 08 & 4 \\
\hline Moderate HL & 176 & 57.9 & 0 & 0 \\
\hline
\end{tabular}

In figure-1 shows distribution of NIHL in different age groups of study subjects $(n=600)$ where highest frequency of hearing loss was found in 30-40 years age group. The following figure is given below in detail:

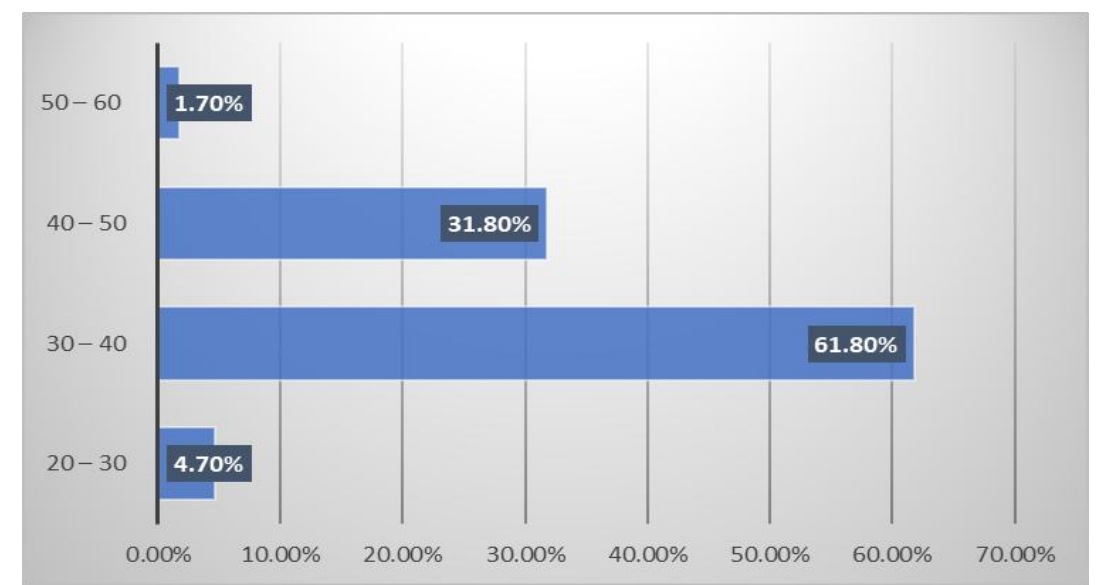

Figure-1: Distribution of NIHL in different age groups of study subjects $(n=600)$. 
In table-2 shows distribution of hearing loss in both groups where $50.7 \%$ patients in group-A had hearing loss where as only $4 \%$ in group-B had this problem, the following table is given below in detail:

Table-2: Distribution of hearing loss in both groups

\begin{tabular}{|l|c|}
\hline Group & $\%$ \\
\hline Group-A & $50.70 \%$ \\
\hline Group-B & $4 \%$ \\
\hline
\end{tabular}

In figure-2 shows distribution of hearing loss among the study groups where in group-B 96\% were normal and $4 \%$ were faced hearing loss. The following figure is given below in detail:

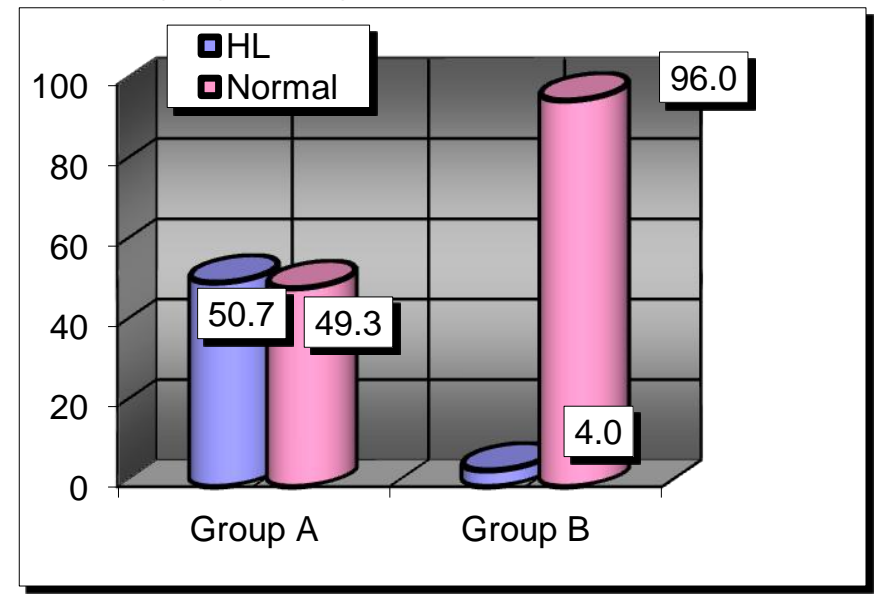

Figure-3: Distribution of hearing loss among the study groups

In figure- 4 shows mean durations of employment among the cases according to diagnoses where mean duration of employment among the cases according to hearing loss in 8.67 and for normal cases 6.30. The following figure is given below in detail:

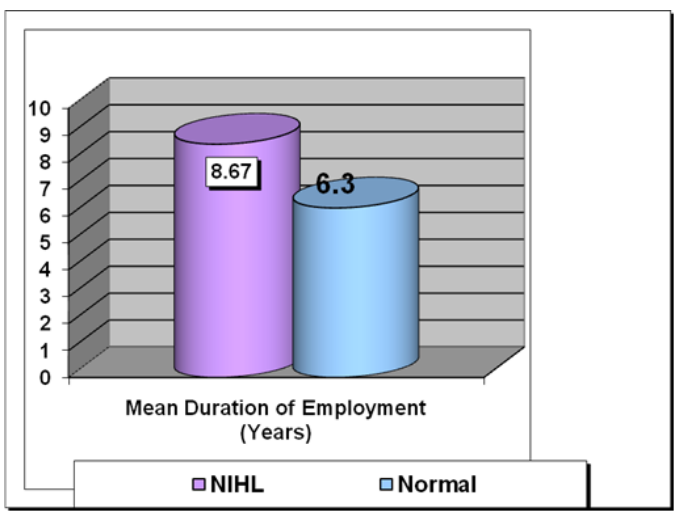

Figure-4: Mean durations of employment among the cases according to diagnoses

In table-3 shows statistics of employment duration and exposure related variables among the cases according to the diagnosis where mean duration of employment of the cases in NIHL is 8.67. In 2-35 years range. The mean duration of employment for normal hearing status is 6.30 in 2-20 years range. Independent $t$ test was done to find the differences between the means. It was found highly significant $(\mathrm{p}<0.001)$.

In daily exposure the cases of NIHL have daily exposure in 8-12 hours range with weekly exposure in 40-96 hours range. In normal hearing status daily exposure is in 8-9 hours range and weekly exposure in 40-54 hours range. The following table is given below in detail:

Table - 3: Statistics of employment duration and exposure related variables among the cases according to the diagnosis (with independent samples $\mathrm{t}$ - test significance)

\begin{tabular}{|c|c|c|c|c|c|c|c|}
\hline & Diagnosis & $\mathrm{N}$ & Mean & $\pm \mathrm{SD}$ & Median & Range & Sign. \\
\hline \multirow{3}{*}{$\begin{array}{l}\text { Duration } \\
\text { Employment } \\
\text { (Years) } \\
\end{array}$} & NIHL & 304 & 8.67 & 5.00 & 8.00 & $2-35$ & \multirow{3}{*}{$\begin{array}{c}\text { t }=7.091 \\
\mathrm{P}=0.000 \\
\text { Highly Significant }\end{array}$} \\
\hline & Normal & 296 & 6.30 & 2.87 & 6.00 & $2-20$ & \\
\hline & TOTAL & 600 & 7.50 & 4.26 & 7.00 & $2-35$ & \\
\hline & Diagnosis & $\mathrm{N}$ & Mean & $\pm \mathrm{SD}$ & Median & Range & Sign. \\
\hline \multirow{3}{*}{$\begin{array}{l}\text { Daily Exposure } \\
\text { (Hours) }\end{array}$} & NIHL & 304 & 8.54 & 0.57 & 9.00 & $8-12$ & \multirow{3}{*}{$\begin{array}{c}\mathrm{t}=2.294 \\
\mathrm{P}=0.022 \\
\text { Significant }\end{array}$} \\
\hline & Normal & 296 & 8.44 & 0.50 & 8.00 & $8-9$ & \\
\hline & TOTAL & 600 & 8.49 & 0.54 & 8.00 & $8-12$ & \\
\hline & Diagnosis & $\mathrm{N}$ & Mean & $\pm \mathrm{SD}$ & Median & Range & Sign. \\
\hline \multirow{3}{*}{$\begin{array}{l}\text { Weekly Exposure } \\
\text { (Hours) }\end{array}$} & NIHL & 304 & 46.28 & 6.84 & 45.00 & $40-96$ & \multirow{3}{*}{$\begin{array}{c}\mathrm{t}=8.740 \\
\mathrm{P}=0.000 \\
\text { Highly Significant }\end{array}$} \\
\hline & Normal & 296 & 42.49 & 2.98 & 40.00 & $40-54$ & \\
\hline & TOTAL & 600 & 44.41 & 5.62 & 45.00 & $40-96$ & \\
\hline
\end{tabular}

$\mathrm{N}=$ total number of cases 


\section{Discussion}

This study was conducted in a cement industry situated in Chittagong to explore the problem of hearing among its workers. Different variables were selected for the study in accordance with this statistical significance or relevance. The dependent variable was noise induced hearing loss (NIHL) which was characterized from evidence of sensorineural hearing deficit in the audiometric examination. The independent variables were age, sex, length of service in the industry, total length of exposure to occupational noise (estimated from the workers reported individual perception of exposure to noise over the course of their working lives) and family history of hearing loss. The present study highlights the hearing status of the workers and the relation of age, exposure to noise and employment duration on the hearing status. This study could help the policy makers of the industries to monitor the noise level and for taking necessary steps to protect the hearing status of the workers.

In this study, a total number of 800 subjects were selected. Among them, 600 were selected as case working in the cement industry. 200 age and sex matched healthy medical staffs were selected as control.

In our study, the most noisy area was the crusher unit and ball milling with noise level upto $105 \mathrm{~dB}$. In Iran and in Tanzania and Nigeria, these units had sound level $>106 \mathrm{~dB}$. Their studies showed that the workers in this department had NIHL due to daily exposure of this sound level more than 8 hours ${ }^{[5][6]}$. In our study the workers of the these department have NIHL due to noise exposure $>90$ $\mathrm{dB}$ for more than 8 hours per day. So, our finding is same to their findings.

A study done in Australia found that hearing impairment is increased with increased age (35 years onwards) ${ }^{[6][7]}$. In our study hearing impairment was found to the workers age above 38 years. The mean age for NIHL is $38.64 \&$ for normal hearing status the mean age is 36.36 . So, the independent t-test is highly significant ( $p$ $<0.001)$. This study, showing hearing impairment with increased age, was similar to the study done in Australia. ${ }^{[8][9]}$

The duration of employment for the cases was in between 2 to 20 years. Among them, the number of NIHL below 5 years $90(29.6 \%), 5$ to 10 years $124(40.8 \%), 10-20$ years $83(27.3 \%)$ and more than 20 years $7(2.3 \%)$ was found. In case of normal hearing status the duration of employment below 5 years $90(30.4 \%), 5-10$ years $183(61.8 \%)$ and $10-20$ years $23(7.8 \%)$ was found. So, the number of NIHL incases with duration of employment 10 years onwards. Here the cases of NIHL have mean duration of employment (years) 8.68 and for normal cases 6.30. The independent sample $t$ - test is highly significant $(p<0.001)$.

\section{Conclusion}

We can conclude that, the hearing loss caused by exposure to occupational noise has multiple consequences at both the individual and the social level. While various factors contribute to the occurrence of occupational noise induced hearing loss (NIHL) like age, sound level and duration of noise exposure, duration of employment and lack of preventive measures. Lack of knowledge about hearing loss and proper use of protective measures influence hearing loss in cement industries. Further study should be conducted to better outcome.

- Similar study with large sample size and of longer duration.

- Consideration of Vibration (either handarm or whole body) and ambient temperature for any potential contribution in increasing the risk of threshold shift.

- Prospective study provided with hearing protective devices (HPD).

- Study with the use Otoacoustic Emissions (OAEs).

\section{References}

1. Kamal AA, Sayed GM, Hassan MH, Massoud AA. Usage of personal protective devices among Egyptian industrial workers. Am J Ind Med 1988,-13: 707-16. 
2. Delleman NJ, DulJ. Sewing Machine operation: workstation adjustment, working posture and workers perceptions, Int J Ind Engineering 2003;30: 341-54.

3. Panmalam P, Kamalamma N, Gangun AK. Occupational health problems of workers in industrial units Indian $\mathrm{J}$ Textiles CXV 1992:63:369-72.

4. International Labor Organization (ILO). Encyclopedia of Occupational Health and Safety 411' Edition, Geneva. 1998; 2: 50.7 $-50.12$.

5. Simpson M, Bruce R. Noise in America: the extent of the noise problem. U.S. Environmental Protection Agency, 1981. ERA Report No. 550/9-81-101.

6. U.S. Department of Labor, Occupational Safety and Health Administration (USOOL OSHA). Noise and 1-learing Conservation, 2002.

7. European Agency for Safety and Health at Work (EASI-1W). Monitoring the State of Occupational Safety and Health in the European Union - Pilot Study, Luxembourg. 2 metallurgical company. Rev Saudi Publican 2005; 39(2): 151 - 64.

8. Patei VS, Ingle ST. Occupational noise exposure and hearing loss among pulse processing workers. Environmentalist 2008; 28:358 - 65.

9. Mahmoud TM, EI-Megeed I-1A, El-Din MA, Ibrahim HDF. A study of occupational health hazards among assiut spinniing factory workers. Ass Univ Bull Environ Res 2004; 7(1): 63 - 70. 